\title{
Activity of Enzymes and Trace Element Content in Bee Honey
}

\author{
L. VORLOVÁ, O. ČELECHOVSKÁ \\ Department of Biochemistry and Biophysics, Faculty of Veterinary Hygiene and Ecology, \\ University of Veterinary and Pharmaceutical Sciences, Brno, Czech Republic \\ Received March 11, 2002 \\ Accepted June 19, 2002 \\ Abstract \\ Vorlová L., O. Čelechovská: Activity of Enzymes and Trace Element Content in Bee Honey. \\ Acta Vet. Brno 2002, 71: 375-378. \\ The objective of this study was to assess the relation between the activity of enzymes (invertase \\ and diastase) and the contents of trace essential elements ( $\mathrm{Fe}, \mathrm{Mn}, \mathrm{Zn}$ and $\mathrm{Cu}$ ) and risk elements \\ $(\mathrm{Pb}, \mathrm{Cd}$ and $\mathrm{Hg})$. A collection of thirty honey samples from various regions of the Czech Republic \\ was arranged into three groups by the botanical origin of honeys (blossom-rape, blossom- \\ multifloral and honeydew), and analysed. The differences in copper content reached high \\ significance $(P<0.01)$ between honeydew $\left(1.5 \pm 0.4 \mathrm{mg} \cdot \mathrm{kg}^{-1}\right)$ and blossom-multifloral $(0.7 \pm 0.5$ \\ $\left.\mathrm{mg} \cdot \mathrm{kg}^{-1}\right)$ or blossom-rape honey $\left(0.3 \pm 0.2 \mathrm{mg} \mathrm{kg}^{-1}\right)$ samples, and $(P<0.05)$ between blossom- \\ multifloral and blossom-rape honey samples. A significant correlation was found between the \\ activity values of invertase and diastase $(\mathrm{r}=0.8072, P<0.01)$, and between the enzyme activity \\ and the copper content (invertase $/ \mathrm{Cu} \mathrm{r}=0.5192, P<0.05$; diastase $/ \mathrm{Cu} \mathrm{r}=0.4868, P<0.05$ ). No \\ significant correlation was found between the enzyme activity and the content of \\ hydroxymethylfurfural (HMF). Honeydew contained higher concentrations of essential and risk \\ elements and simultaneously showed higher enzyme activity than honey blossom. \\ Invertase, diastase, essential metals, risk elements
}

Enzymes are the most important and also the most interesting honey components. They are accountable for the conversion of nectar and honeydew to honey, and serve as a sensitive indicator of the honey treatment. In some countries, the specification of enzymes is a binding legal indicator (Bogdanov et al. 1987; Codex Alimentarius 1993; Oddo et al. 1999). Even though the enzyme role was not found in human diet, the activity of enzymes participates in the biological value of honey. The contents of essential trace elements also participate in the nutritional value of honey and it is one of the factors affecting the colour of honey. Literature presents a whole spectrum of physicochemical properties of honeys from separate geographical regions, though mostly without any closer specification of their botanical origins (Yilmaz and Yavuz 1999; Caroli et al. 1999; Kump et al. 1996).

The objective of this study was to determine the enzyme activity of $\alpha$-glucosidase (invertase) and $\alpha$ - and $\beta$-amylase (diastase), the contents of hydroxymethylfurfural (HMF = 5-hydroxymethylfuran-2-carbaldehyde) and the contents of essential and risk trace elements for three groups of honey samples sorted by their botanical origins; and then, to assess the differences between these groups and to find out the influence of the particular analytes on the activity of enzymes by statistical methods.

\section{Materials and Methods}

A collection of thirty honey samples was analysed. All samples were obtained directly from beekeepers in various regions of the Czech Republic during the year 2000. The honey samples were sorted by their botanical origin into three groups: blossom-multifloral $(n=10)$, blossom-rape $(n=10)$, and honeydew $(n=10)$. In each sample, we determined the enzyme activity of invertase and diastase and the content of essential $(\mathrm{Cu}, \mathrm{Fe}, \mathrm{Mn}$ and 
$\mathrm{Zn})$ and contaminant $(\mathrm{Cd}, \mathrm{Pb}, \mathrm{Hg})$ trace elements. Before being analysed, all honey samples were kept in glass vessels at room temperature, and protected from light. The enzyme activity and the content of HMF were determined within a month after honey extraction.

Analytical methods used for the individual analytes:

The activity of enzymes

Invertase $(\alpha$-glucosidase, EC 3.2.1.20) - measured by the method by Siegenthaler with spectrophotometric evaluation (UV/VIS spectrometer Lambda 11, Perkin Elmer, USA). The results are given in units of activity per $1 \mathrm{~kg}$ of honey (U/kg), alternatively as an invertase number (IN) (Bogdanov et al. 1997).

Diastase $(\alpha$ - and $\beta$-amylase, EC 3.2.1.1, EC 3.2.1.2) - by the Shade method. The results are given as a diastase number (DN) (Bogdanov et al. 1997).

HMF (5-hydroxymethylfuran-2-carbaldehyde alternatively 5-hydroxymethylfurfural) - measured by the Winkler method (Bogdanov et al. 1997).

$\mathrm{Cu}, \mathrm{Fe}, \mathrm{Mn}, \mathrm{Zn}$ - measured using a flame technique AAS (atomic absorption spectrometry, model Z-5000, Perkin-Elmer, USA) after the dissolution of the sample ash in $0.2 \mathrm{~mol} / 1 \mathrm{HCl}$ (ash - by burning in a muffle furnace LM 312.11, MLW Germany; Bogdanov et al. 1997).

$\mathrm{Pb}, \mathrm{Cd}$ - by an electrothermal technique AAS after the preceding mineralization by nitric acid in a microwave autoclave Uniclever (Plasmatronica, Poland). The atomic absorption spectrometer (model Z-5000) was set to the conditions recommended by the manufacturer (Perkin-Elmer, USA). The used AAS method showed the following detection limits (defined as the concentration equivalent to 3 times the standard deviation of the analytical blank signal, $\left.\mathrm{n}=10: \mathrm{Cd}=0.25 \mu \mathrm{g} \cdot \mathrm{kg}^{-1}, \mathrm{~Pb}=4.5 \mu \mathrm{g} \cdot \mathrm{kg}^{-1}\right)$.

$\mathrm{Hg}$ - the measurement was done on a mercury analyzer AMA 254 (Altec Ltd., the Czech Republic). Detection limit $0.01 \mathrm{ng} \mathrm{Hg}$.

The precision and accuracy of the AAS methods was verified using the recovery test that ranged from $94.2 \%$ to $105.1 \%$. The resulting data were processed by statistical package Unistat ${ }^{\circledR}$, version 5.1. The mean values of analyte concentrations and standard deviations were calculated for each separate group of honey samples and submitted to the correlation analysis and Student's $t$-test.

\section{Results and Discussion}

Fig. 1 shows the content of the HMF and the essential elements for each separate group of honey samples. The content of the HMF was very low for all three groups (blossommultifloral: $3.04 \pm 1.93$; blossom-rape: $1.74 \pm 1.57$; honeydew: $5.83 \pm 5.62$

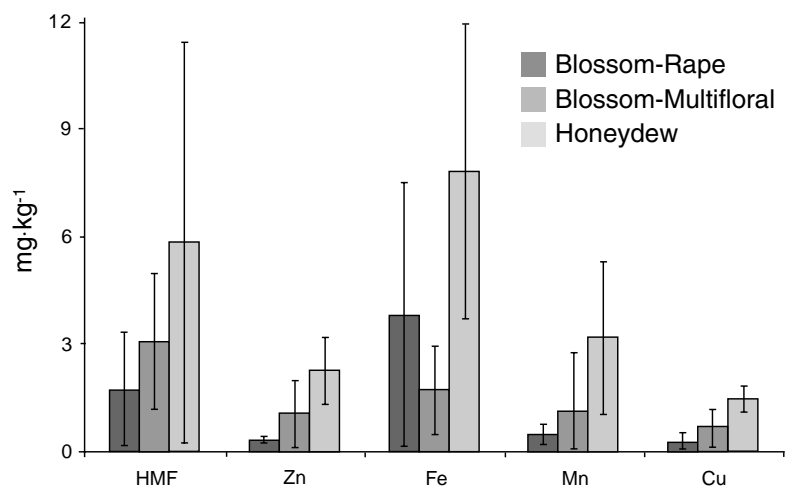

Fig. 1. The content of the HMF and essential elements in honeys grouped by botanical origin (mean \pm SD) $\left.\mathrm{mg} \cdot \mathrm{kg}^{-1}\right)$. The content of the essential trace elements $(\mathrm{Fe}$, $\mathrm{Mn}, \mathrm{Zn}$, and $\mathrm{Cu}$ ) varied for each group; however, only the $\mathrm{Cu}$ content showed significant differences (Tab. 1). The concentrations of metals in honeydew honeys found by us are in agreement with those found by Yilmaz and Yavuz (1999) and RodriguezOtero et al. (1994). Except for the zinc concentration that Kump et al. (1996) reported to be higher, the concentrations of the other elements were consistent, too. The concentrations of metals in blossom-multifloral and blossom-rape honey samples were lower than the concentrations in honeydew samples. To our knowledge, there are no studies that would analyze systematically honeys grouped by their botanical origin. Therefore comparison with literature references is difficult. Literature data report only the contents of the individual metals without sorting the honey samples by their botanical origin.

The concentrations of potentially toxic elements $(\mathrm{Pb}, \mathrm{Cd}, \mathrm{Hg}$ - Table 2) were very low (median $\mathrm{Pb}: 0.053 \mathrm{mg} \cdot \mathrm{kg}^{-1}$; Cd: $3.3 \mu \mathrm{g} \cdot \mathrm{kg}^{-1} ; \mathrm{Hg}: 1.2 \mu \mathrm{g} \cdot \mathrm{kg}^{-1}$ ). Statistically significant 
Table 1

Statistically significant differences in the content of the particular components between three groups of honey samples sorted by botanical origin $(* P<0.05, * * P<0.01)$

\begin{tabular}{|l|c|c|}
\hline Honey & Blossom-Rape & Honeydew \\
\hline $\begin{array}{l}\text { Blossom- } \\
\text { Multifloral }\end{array}$ & $\mathrm{Cu}^{*}$ & $\begin{array}{c}\mathrm{Cu}^{* *}, \mathrm{Fe}^{*}, \mathrm{Zn}^{*}, \mathrm{Hg}^{*}, \\
\mathrm{Cd}^{*}, \text { Diastase, } \\
\text { Invertase }\end{array}$ \\
\hline Blossom-Rape & - & $\begin{array}{c}\mathrm{Cu}^{* *}, \mathrm{Mn}^{* *}, \mathrm{Zn}^{* *}, \\
\mathrm{Hg}^{*}, \mathrm{Cd}^{*}\end{array}$ \\
\hline
\end{tabular}

differences $(P<0.05)$ were found in the content of $\mathrm{Cd}$ and $\mathrm{Hg}$ between honeydew and blossommultifloral honey samples, and between blossom-rape and honeydew samples (Table 1), which factually comports with our earlier work (Čelechovská and Vorlová 2001).

Table 2

Content of risk elements in honey samples (mean \pm SD)

\begin{tabular}{|l|c|c|c|}
\hline \multirow{2}{*}{ Honey } & $\mathrm{Pb}$ & $\mathrm{Cd}$ & $\mathrm{Hg}$ \\
\cline { 2 - 4 } & $\left(\mathrm{mg} \cdot \mathrm{kg}^{-1}\right)$ & \multicolumn{2}{|c|}{$\left(\mu \mathrm{g} \cdot \mathrm{kg}^{-1}\right)$} \\
\hline Blossom-Rape & $0.096 \pm 0.056$ & $1.55 \pm 0.58$ & $1.05 \pm 0.17$ \\
Blossom-Multifloral & $0.042 \pm 0.033$ & $1.85 \pm 1.75$ & $1.08 \pm 0.36$ \\
Honeydew & $0.095 \pm 0.040$ & $19.3 \pm 13.9$ & $1.91 \pm 0.58$ \\
\hline
\end{tabular}

Fig. 2 shows the diastase and invertase activity values for three separate groups of honey samples. Both enzymes showed statistically significant differences $(P<0.05)$ between blossom-multifloral and honeydew honey samples (Table 1). The enzyme activity values found by us were higher than those published by Golob and Plestenjak (1999) and Yilmaz and Yavuz (1999) and lower than values published by Oddo et al. (1999); the honey samples examined in the abovementioned studies were from different regions. After performing correlation analysis between the activity values of enzymes and the content of essential and risk elements, we found some significant correlative dependences $(P<0.05)$ between the diastase

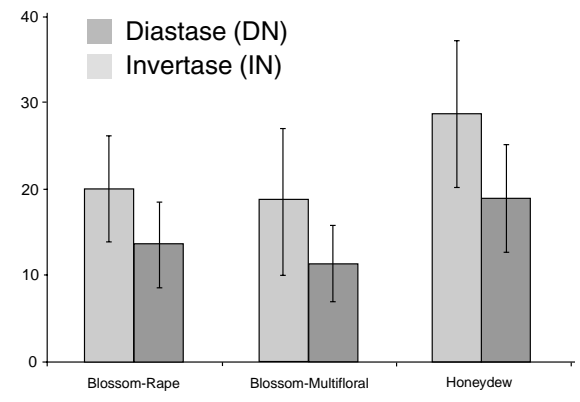

Fig. 2. Activity of enzymes for each honey group (mean \pm SD) activity value and the $\mathrm{Cu}$ content $(\mathrm{r}=0.49)$, and between the invertase activity value and the $\mathrm{Cu}$ content $(\mathrm{r}=0.52)$.

The highly significant correlation $(P<0.01, \mathrm{r}=0.81)$ between diastase and invertase activity values is also in agreement with the study by Oddo et al. (1999). However, we found no significant correlation between the enzyme activity and the HMF content.

\section{Enzymová aktivita a stopové prvky ve včelím medu}

Předmětem studie jsou vztahy mezi aktivitou enzymů (invertasy a diastasy) a obsahem stopových esenciálních (Fe, $\mathrm{Mn}, \mathrm{Zn}, \mathrm{Cu})$ a rizikových $(\mathrm{Pb}, \mathrm{Cd}$ a $\mathrm{Hg})$ prvků. Vzorky medů byly získány od včelařů z různých oblastí České republiky v roce 2000 . Bylo analyzováno 30 vzorků medů rozdělených do skupin podle původu (květové-řepkové, květové-smíšené 
a medovicové). Skupina medovicových medů se statisticky významně lišila $\mathrm{v}$ obsahu esenciálních i rizikových prvků od ostatních skupin. Měd vykazovala statisticky vysoce významný rozdíl $(P<0,01)$ mezi medovicovými $1,5 \pm 0,4 \mathrm{mg} \mathrm{kg}^{-1}$ a květovými-smíšenými $0,7 \pm 0,5 \mathrm{mg} \cdot \mathrm{kg}^{-1}$ nebo květovými-řepkovými $0,3 \pm 0,2 \mathrm{mg} \cdot \mathrm{kg}^{-1}$ medy, statisticky významný rozdíl $(P<0,05)$ mezi květovými-smíšenými a květovými-řepkovými medy. Byly nalezeny signifikantní korelace mezi aktivitou invertasy a diastasy $(\mathrm{r}=0,8072, P<0,01)$, a mezi enzymovou aktivitou a obsahem $\mathrm{Cu}$ (invertasa/Cu $\mathrm{r}=0,5192, P<0,05$; diastasa/ $\mathrm{Cu} \mathrm{r}=$ $0,4868, P<0,05)$. Nebyla nalezena statisticky významná korelace mezi enzymovou aktivitou a obsahem HMF (5-hydroxymethylfurfural). Medovicový med obsahoval vyšší koncentrace esenciálních a rizikových prvků a současně vykazoval vyšší enzymovou aktivitu než med květový.

\section{Acknowledgements}

The research support was provided by the Ministry of Education, Youth and Sports of the Czech Republic, grant No 162700005 .

\section{References}

BOGDANOV, S, MARTIN, P, LÜLLMANN, C 1997: Harmonised Method of the European Honey Commission. Apidologie (extra issue), p. 59

BOGDANOV, S, RIEDER, K, RÜEGG, M 1987: Neue Qualitätskriterien bei Honiguntersuchungen. Apidologie 18: $267-278$

CAROLI, S, FORTE, G, IAMICELI, AL, GALOPPI, B 1999: Determination of essential and potentially toxic trace elements in honey by ICP techniques. Talanta 50: 327-336

CODEX ALIMENTARIUS STANDARD FOR HONEY, 1993: Ref. Nr. CL 1993/14-SH FAO and WHO, Rome, $27 \mathrm{p}$.

ČELECHOVSKÁ, O, VORLOVÁ, L 2001: Groups of honey - physicochemical properties and heavy metals. Acta Vet Brno 70: 91-95

GOLOB, T, PLESTENJAK, A 1999: Quality of Slovene honey. Food technol Biotechnol 37: 195-201

KUMP, P, NEČEMER, M, NAJDER, J 1996: Determination of trace elements in bee honey, pollen and tissue by total reflection and radioisotope X-ray fluorescence spectrometry. Spectrochim Acta Part B 51: 499-507

ODDO, LP, PIAZZA, MG, PULCINI, P 1999: Invertase activity in honey. Apidologie 30: 57-65

RODRIGUEZ-OTERO, JL, PASEIRO, P, SIMAL, J, CEPEDA, A 1994: Mineral content of the honeys produced in Galicia. Food Chem 49: 169-171

YILMAZ, H. YAVUZ, O 1999: Content of some trace metals in honey from south-eastern Anatolia. Food Chem 65: $475-476$ 